\title{
MODERN BUDDHISM AND ITS CULTURAL TRANSLATIONS. REFLECTIONS FROM A QUALITATIVE CASE STUDY OF TWO EUROPEAN ZEN MONKS
}

ISMAEL APUD

Assistant Teacher, Faculty of Psychology, Universidad de la República, Montevideo, Uruguay. ismaelapud@psico.edu.uy·https://orcid.org/oooo-0003-4237-9365

AвSTRACT. Buddhism has expanded around the world as a variety of schools and branches. In Western countries, the encounter between modernity and Buddhism has resulted in a heterogenic cultural product called 'Modern Buddhism.' For several authors, it is a recent invention, quite different from 'Traditional Buddhism.' But is Modern Buddhism an exception in the history of Buddhism? The current article critically reflects on this question, using the notion of 'cultural translation' and, to do so, presents a qualitative case study of two European Zen monks. One is a Catalan monk from Spain; the other is a German abbot living in Japan. Interpretations and cultural translations of Buddhist ideas and practices are regarded as being influenced by the background of Modern Buddhism and by the singular personal biographical trajectories of the two monks. It will be argued that the cultural translations described in Modern Buddhism are not an exception but an expected interpretation.

KEYwords: Modern Buddhism; Sōtō Zen; Case Study; Cultural Translation. 
EL BUDISME MODERN I LES SEVES TRADUCCIONS CULTURALS. REFLEXIONS A PARTIR D'UN ESTUDI QUALITATIU DE CASOS AMB DOS MONJOS ZEN EUROPEUS

Resum. El budisme s'ha expandit per tot el món en forma de tot un plegat d'escoles i branques. Als països occidentals, la trobada entre la modernitat i el budisme s'ha traduït en un producte cultural heterogeni anomenat 'budisme modern'. Per a diversos autors, això suposa una invenció recent, molt diferent del budisme tradicional. Però, és el budisme modern una excepció a la història del budisme? Aquest article reflexiona de manera crítica sobre aquesta qüestió, utilitzant la noció de 'traducció cultural' i, per a això, presenta un estudi qualitatiu de casos amb dos monjos zen europeus. Un és un monjo català i l'altre és un abat alemany que viu al Japó. Es considera que les interpretacions i les traduccions culturals de les idees i de les pràctiques budistes estan influïdes pels antecedents del budisme modern i per les trajectòries biogràfiques personals i individuals d'ambdós monjos. Es defensarà que les traduccions culturals descrites al budisme modern no són una excepció, sinó una interpretació previsible.

Paraules ClaU: Budisme modern; Sōtō Zen; estudi de casos; traducció cultural 


\section{Introduction}

Since the second half of the 19th century, Buddhism has expanded globally across Western countries, turning into what is now known as 'Modern Buddhism.' It is usually considered to be a recent phenomenon, quite different from 'traditional Buddhism,' and sometimes going beyond the boundaries of what defines Buddhism as such. Despite its heterogeneity, Modern Buddhism can be characterized by such general traits as the rationalization, demythologization, psychologization, and/ or scientification of Buddhist ideas; the devaluation of ritualistic and magical aspects of previous folk beliefs and practices; the emphasis on meditation as a core element of being a Buddhist; the privatization and deinstitutionalization of practices and beliefs; and the depiction of Buddhism as a democratic practice and a philosophy of equality (Almond, 1988; Baumann, 2001; Berkwitz, 2006; Cabezón, 2003; Coleman, 2001; Heine and Prebish, 2003; López Jr., 1995; 2008; McMahan, 2004; Prebish, 1999; Tweed, 2000).

The assumption of these essential features is the result of how Buddhism was interpreted by Western culture after the colonial milieu of the second half of the 19th century. Before, Western accounts of Buddhism had been provided by travellers, diplomats, traders, and missionaries, but they were largely unconnected and had little impact on Western culture (Almond, 1988). Later, in the colonial context of the Victorian 19th century, Buddhism started to capture the attention of a wide reading middle- and upper-class public. Translations of traditional texts from Pāli to English were printed, thus democratizing knowledge previously restricted to authorities and monks. Buddhism was portrayed as a rational practice and a mystic philosophy, refined from the superstitious and magical aspects of Asian Buddhism. As a result, the 'essence' of Buddhism was constructed, through an image of Buddha purged of myths and superstitions (Almond, 1988; López Jr., 2008).

The construction of 'Buddhism' as a unified object of study was one more piece in the puzzle of the colonial development of different cultural alterities, including shamanism (Taussig, 1993; Znamenski, 2007) and Orientalism (Asad, 1975; Said, 1994). In the ideal construction of non- 
Western cultural alterities, academics have played a leading role, not only by studying different religions but also by transforming them into a variety of novel forms. Disciplines such as religious studies, anthropology, psychology, and classical studies attributed new meanings to religion, prompting new forms of practices and beliefs to emerge (von Stuckrad, 2014). In the case that concerns us here, from the 19th century onwards scholars have been producing a discrete object of study called Buddhism. This academic construction interacted with a variety of Buddhist practices, thus transforming them in both Western and Eastern countries.

The academic study of Buddhism can be framed within the tensions between the Enlightenment and Romanticism. On one hand, the Enlightenment considered science as the triumph of Western culture over superstition and religion. Under this view, Buddhism was often portrayed as a nihilistic, pessimistic, and archaic tradition. But at the same time, many scholars found in Buddhism a set of beliefs closer to science than those of any other religion. One of the main arguments was that Buddha seemed to downplay divine intervention and stressed the importance of knowing the natural laws of the universe (López Jr., 2008). On the other hand, Romanticism confronted the materialistic and rationalistic worldview of natural sciences, and proposed a more enchanted, relativistic, and artistic view of history and culture. Under this tradition, Buddhism was considered a spiritual alternative to both Christianity and scientific materialism. Among these tensions, new images of Buddha emerged: an ascetic sage, a social reformer, a wise philosopher, a practical scientist, a folk psychotherapist, an atheist, among others (Cabezón, 2003; McMahan, 2004).

Asian Buddhists were also cocreators of Modern Buddhism. They were actively translating Buddhism into Western terms, motivated by political and cultural interests. For example, in Eastern countries such as Japan and Sri Lanka-Ceylon during colonization-nationalistic revival movements reinterpreted Buddhist traditions so that they could be used as instruments of emancipation against Western hegemony. They usually combined Buddhist beliefs with Western values of cultural autonomy and 
human freedom. In the case of Sri Lanka, Sven Bretfeld (2012) analyses how the Theravada tradition underwent major changes during the 19th and 20 th centuries, in the wake of a growing anti-colonial movement against Christian missionary activity. Within this historical and political context, the equivalence between Buddhism and science was used to discredit missionary colonial ideas. In the case of Japan, Donald López Jr. (2008) describes the controversies between Buddhist and Western scientific worldviews, when heliocentric theory was introduced in the late 18th century. On one side, Buddhist monks such as Fumon Entsū 圓通 defended the Mount Sumeru Theory against the Western modern cosmological worldview. On the other side, Jōdo Shinshū 浄土真宗and priests like Shimaji Mokurai 島地黙雷 and Inoue Enryō 井上円了 argued that Mount Meru cosmography was only an expendable and outdated element of Indian Mythology. Similarly, the Sōtō Zen priest Taiken Kimura 木村泰賢 distinguished 'original Buddhism' (genshi bukkyō 原始 佛教), from popular beliefs, Mount Meru cosmography included.

For the specific case of Zen, Robert Sharf (1995) analyses how a new image was constructed by an elite circle of Japanese intellectuals such as Shaku Sōen 釈宗演, Nukariya Kaiten 忽滑谷快天, and Daisetsu Teitaro Suzuki 鈴木大拙貞太郎. The process can be related to the Westernization and modernization of Japan during the Meiji period. As a reaction to the anti-Buddhist policy of the government, a vanguard of Buddhist leaders and intellectuals created what is known as New Buddhism (shin bukkyo 新仏教), in opposition to sectarian traditions of the time, depicted as corrupted and outdated. According to the author, Zen practice was introduced to Westerners using an idealized image of a 'modern,' 'cosmopolitan,' 'humanistic,' and 'socially responsible' kind of Buddhism. Zen was presented as the 'true' and 'original' Buddhism, concerned with the achievement of a 'pure experience.'

One final important hallmark in the construction of Modern Buddhism can be traced back to the second half of the 2oth century. In a post-World War II context, a new global crisis appeared in Western culture. The ties between science, technology, the arms industry, and pollution once again led to social disenchantment with Western modern 
emancipatory projects (Lyotard, 1993). In response, countercultural and spiritual movements emerged, including the popularization of alternative non-Western paradigms: 'English gurus' from India promoting new spiritual paths, native shamans from Latin America offering rituals with psychedelics, and a growing interest in Buddhist meditation and other Eastern practices. In this context, new dialogues between Buddhism and science appeared, as well as postmodern appropriations of Buddhist ideas and practices, quite separate from the secularized scientific project of modernity (Berkwitz, 2006; McMahan, 2008).

Nowadays, Modern Buddhism is described as a demythologized, rationalized and psychologized form of Buddhism (Baumann, 2001), secularized and incorporated into modern Western narratives and practices (McMahan, 2004). Modern Buddhism seems to be a recent and sui generis construction, quite unlike practices and doctrines that could be labelled as traditional Buddhism. But how different is Modern Buddhism from traditional forms of Buddhism? Is it an exception in the history of Buddhism or is it just one more version in the wide variety of forms Buddhism has assumed? What are the core aspects of Buddhism? And, from a psychological point of view, what do you have to believe or do in order to be considered a Buddhist? Which boundaries cannot be crossed by someone still wishing to be considered Buddhist? Do we need to believe in karma, reincarnation, or nirvana in order to be a true Buddhist?

From an anthropological perspective, I propose to explain the creation of Modern Buddhism in terms of cultural translation, just as I have discussed elsewhere the case of neo-shamanic practices in Latin America (Apud, 2015) and Spain (Apud, 2017; 2020). I defined cultural translation as the transformations that occur to symbols, beliefs, and practices when transferred from one cultural context to another. In the religious field, cultural translation usually results in different syncretic products: interpretations of foreign ideas as metaphors of local ones, the redesign of rituals to adapt to local needs and worldviews, novel bricoleur compositions mixing local and foreign cultural traits, and others. 
Cultural translation is not a unilateral process. It usually results in changes on both sides of the cultural exchange, something I call 'double assimilation' (Apud, 2015). Modern Buddhism is a good example of how the two-sided process of cultural translation works. On the Western side, there is an adaptation of meditative practices and cosmological beliefs to the spiritual, and scientific Western background. On the Eastern side, there is an appropriation of scientific ideas for different cultural, political, and academic struggles of legitimacy. It is important to stress that cultural translation is by no means an exception in the history of Buddhism. In fact, cultural flexibility, adaptability, and innovation have been major features of Buddhism throughout its history, allowing it to spread all over Asia in a wide range of local appropriations and translations.

But explaining Modern Buddhism only in terms of cultural translation has weaknesses, too. As cognitive anthropologists point out, the most important weakness is that it rejects other neurological, psychological, and/or ecological levels of explanation that strongly influence cultural transmission (Bloch, 2012; Boyer, 1994; Sperber, 1996). In this article I shall be working with biographical narratives of two modern Western Zen monks, and I would like to stress the importance of a psychological level of analysis to understanding how narratives of the self are produced. According to a long tradition in the psychology of religion, the individual, as a psychological unit, can be considered as the locus where different cultural traditions intersect, dialogue, mix, and transform (Apud, 2020; Bloch, 2012; James, 1902; McNamara, 2009; Starbuck, 1911). The individual as a cognitive unit, acts a creative psychological node, able to innovate, rearrange, and combine her/his different cultural and social trajectories.

\section{Materials and Methods}

The current article presents a biographical study of two Western European monks ordained in the Sōtō Zen school, interviewed during a multisituated ethnographic fieldwork project with Zen groups. My first contact with Buddhism was in Montevideo, Uruguay, in the year 2004. I started my fieldwork with a Sōtō Zen group, as part of a broad study 
about Buddhism in Uruguay, which over the years resulted in several publications (Apud, Clara, and Ruiz, 2013; Apud et alii, 2015a; 2015b). In 2014, I moved to Barcelona. There, I found a centre called Dojo Zen Barcelona Kannon, where I practiced zazen from May 2016 to April 2017. I asked the director of the centre Lluís Nansen Salas, if I could write about his trajectory as a Buddhist practitioner. On 9 April 2017, I interviewed him in the city of Barcelona. To analyse his biographical account, I used other documents too: my personal notes about my own practice, documents that can be found on the webpage of his centre zenkannon.org (including journalistic and television interviews), and books he published about Zen meditation (Salas, 2018; 2017; 2019).

I decided to travel to Japan, so I asked Lluís to recommend a monastery where I could practice zazen, away from the tourist circuits, and closer to real practitioners. He gave me the contact information for Antaiji 安泰寺, a monastery where some of his fellow students stayed. I contacted the abbot of the monastery, Muhō Nölke, by e-mail, and in the month of June, I went to Antaiji for a stay. A year and a half later, I contacted Muhō again, asking for an interview, which he kindly agreed to do on 23 June 2019. For extra documentation I consulted other interviews and writings on the website antaiji.org, and his master's degree dissertation (Nölke, 1992).

\section{Lluís Nansen Salas: A Catalan Bodhisattva}

The arrival of Buddhism in Spain can be framed within the big picture of the historical encounter between Western culture and Buddhism I described above. Before the 19th century, Buddhism was only known through the accounts of missionaries and vassals of the Spanish crown in their travels through Asia. By the end of the 19th century, Buddhism had captured the attention of theosophists interested in spirituality, and of some scholars who considered it a nihilist tradition (Díez de Velasco, 2013). In the first half of the 2oth century, Spain went through a Civil War that led to Francisco Franco's dictatorship. Catholicism was the official religion and monopolized the religious matrix of the country. By the end of 1970s, democracy returned, and the country progressively moved into the age of globalization. The Catholic Church lost much of its influence, 
and new spiritualities started to spread, Eastern traditions included (Prat et alii, 2012).

Díez de Velasco (2013) describes various milestones in the expansion of Buddhism after the arrival of democracy: the first Zen dojo from the lineage of Taisen Deshimaru 弟子丸泰仙 in Seville in 1977; the first Buddhist organization to be registered in the Ministry of Justice in Barcelona in 1982, under the name Karma Kagyu de Budismo Tibetano (Tibetan Karma Kagyu Buddhism); the creation of the Federación de Comunidades Budistas de España (Federation of Buddhist Communities in Spain) in 1991; the award of the legal status of notorio arraigo (official recognition that a religion is fully established in Spain and has a considerable following) by the Spanish government in 2007. According to the author, nowadays there are approximately 300 Buddhist groups in Spain, and about 40,000 regular participants. More than a half of the groups are from the Tibetan tradition, and about 90 groups are from the Zen tradition.

The first Sōtō Zen groups in Spain were connected with Deshimaru and his Association Zen Internationale (AZI), founded in 1970 in France. Deshimaru's visit to Spain in 1981 encouraged different groups to be set up in Andalusia, the Basque Country, Catalonia, and other autonomous communities. He never gave the Dharma Transmission (shihō 嗣法) to any of his students. This was an important obstacle to the continuity of the practice, if we consider that shiho is essential to the master-disciple transmission of the Sōtō Zen doctrine. Therefore, after Deshimaru's death in 1982, European disciples such as Ettienne Mokushō Zeisler, Stéphane Kosen Thibaut, Roland Yuno Rech, and Francisco Dokushō Fernández Villalba had to travel to Japan to receive the shiho from the Japanese Sōtōshu 曹洞宗organization. In Barcelona, the first dojo appeared after Deshimaru's visit to the city. It was located in Montcada Street, in the Gothic neighborhood and it was there that Lluís Salas started to practice zazen.

Lluís Nansen Salas was born in 1965 in Barcelona, the capital of Catalonia. He has a degree in Theoretical Physics from the Universitat Autònoma de Barcelona, but for much of his life he has worked as an IT 
Controller in an insurance company. Since his childhood, Lluís has been disenchanted with mainstream Catholic beliefs, as well as the general Western social lifestyle and cultural values.

I noticed that something was missing. A void that materialistic life left within me, so I started to seek something spiritual [...] I practiced yoga, Aikido... I was looking for modern ways of spirituality [...] I read books about spirituality... Alan Watts... Herman Hesse was an important influence, with the story of Siddhartha [...] I read books of Deshimaru, all of them. And one day, in an Aikido class, one of the practitioners told me: 'I know a temple, here in Barcelona, where Zen is practiced.' And I started to practice there [...] I guess there were no other places for Zen at that time in Barcelona. It was the year 1991 (personal interview with Lluis Nansen Salas, April 9, 2017, translation from Spanish by me).

Lluís describes a biographical trajectory similar to other Western post-modern spiritual seekers in Spain (Prat et alii, 2012). Firstly, his disenchantment with the Catholic church, which is an important institution in the country. Secondly, his dissatisfaction with Western modern materialistic and rational values. Thirdly, his search for alternative emancipatory models, in this case zazen meditation as a spiritual path that connects body and mind. For Lluís and other Buddhist practitioners, meditation is valued as a practice that allows the self to go beyond modern Western rational thinking. It connects practitioners with their bodies, and with sensations that are usually downplayed by Western thought.

At the beginning I felt trapped, like I had reached a dead end... it was because of... the way my rational mind works. By practicing Zen I found a way to get rid of it [...] There were experiences, in some retreats... peak experiences. In some of them you can feel at one with the world... an immense happiness... something that... cannot be expressed with words. I think that those experiences make you realize that liberation is possible. Even if you can touch it for an instant... for a brief moment. It gives you an awareness that liberation is possible and motivates you to continue with the practice. It is like a lightning bolt that lets you see the whole landscape during the night, which shows you that behind the darkness there really is a landscape with mountains and valleys... 
The real and important thing in those experiences is not what you feel but what you leave behind. You release yourself from an attachment within your body, or a resistance you have, and that is what makes you feel joy... a huge joy, a spiritual joy [...] These experiences were produced at moments of intense zazen practice [during sesshin]. Long retreats, of about three, four, even nine days (ibidem)."

Lluís describes how sesshin 接心 made subtle changes to his daily life: he was more aware of the conditioning of everyday life, he recognized embodied emotions better, he became more detached from some worries. At the beginning, zazen was his main interest, and he had little interest in the Buddhist doctrine.

Certainly, I didn't have much interest in the teachings, I was only interested in the practice [...] Years went by and I was strongly committed to the practice... and then I said, OK, if this is Buddhist practice, then I am a Buddhist! (ibidem).

At the time Lluís was beginning his practice, in France, Stéphane Kosen Thibaut decided to leave AZI. As a consequence, the Barcelona group where Lluís was practicing split in two. Lluís decided to follow the group that continued within AZI. In 1994 he made his first visit to the Gendronniere the main AZI temple 15 kilometres from Blois, France - and was ordained as a bodhisattva under the guidance of Roland Yuno Rech.

There were two personal moments that strengthened Lluís's commitment to the practice: in 1992 and 1995, the years in which his two sons were born.

The moment my sons were born coincided with a strong need for spiritual quests, because... it was when Natalia [his wife] was pregnant at the end of 1991 that I started my practice. And the arrival of my second son pushed me further along the spiritual path. It was then that I was ordained a monk in 1995. [...] I think the birth of my sons made me realise the reality of life and death in a way that... I could experience by myself [...] Birth, death... are events that put you in touch with reality again (ibidem). 
In 1995 he became a disciple of the French monk Raphaël Doko Triet, who, in turn, had been a disciple of Deshimaru and abbot of the temple Seikyuji, near Seville (Andalusia, Spain). But tensions between Seikyuji and the group in Barcelona put Lluís in an uncomfortable situation. In 2003 he decided to put his trust once again in the guidance of Roland Yuno Rech. Finally, in 2008, Lluís set up the Dojo Zen Barcelona Kannon. Initially, there were only four members: two friends, his wife Natalia, and himself. Nowadays, the center has about 200 registered members. In 2016 Lluís obtained the shihō from Roland Yuno Rech. Nansen is his ordination name, which means 'sage of the South.'

At Zen Kannon, Lluís and Natalia teach zazen, mindfulness, and Buddhist philosophy. Lluís frequently uses his scientific background to explain Buddhist ideas and practice to a wide audience. He describes the Buddhist idea of emptiness as being similar to superstring theory in physics, he discusses bodhisattva Kannon as an archetype of human nature related to empathy, compassion, and mirror neurons, and he compares the Buddhist notion of interdependence with the atomic forces that bring the material world together. For him, the scientific method and the teachings of Buddha share the same values of truth, experience, and reason. Besides, the ideas of karma and reincarnation are interpreted in a psychologized and secularized style.

In the end, it's all a matter of language. What I mean is that, beneath all those explanations, for example reincarnation, there is a way to explain things using the linguistic resources of traditional cultures [...] In the case of reincarnation... I don't like to use the word reincarnation because Buddha himself teaches us that the self is not permanent. There is no substantive soul to identify as oneself, and which moves to another body. Maybe a more appropriate word is rebirth [...] At the time Buddha explained this, there was a culture that believed in a soul, an àtman that reincarnates [...] To explain what it consisted of, they used the idea of a karmic seed. The word 'seed' is an agricultural metaphor. These karmic seeds are in fact how we are conditioned. Conditionings, mental habits, ... are like seeds, that can eventually flourish any time [...] This conditioning was explained in antiquity as a seed [...] We are full of 
those karmic seeds, and that's what really transmigrates. Not only when we die. These seeds are transmitted to other beings when we are alive. But for Buddha, those karmic seeds were not a soul, because there is no permanent unity [...] We can see this conditioning, these karmic seeds in our daily life. They are like waves, transmitted from person to person. [...] We transmit them to other people through empathy and in other ways (ibidem).

According to Lluís, the wheel of samsāra is made up of the satisfactions and dissatisfactions produced by these seeds, leading us to both desire and suffering. But Lluís prefers the concept of 'intention', which he believes is a more accurate term than the classic concept of 'desire.'

Intention is a general and deeper phenomenon [than desire]. When we talk about desire there are certain nuances... the desire for food, sex, things. But the word 'intention' has a wider meaning. Intention is the basis on which our ordinary mind functions. The ordinary mind makes us like the things we like, and dislike what we do not like. It is formed and rooted in intention. We cannot escape from it willingly, because if we wish it, we would be using our intention. If there is intention, we stay in the ordinary mind. We cannot intentionally free ourselves from the conditioning of our ego and our mental habits [...]

During zazen, we sit. At first with an intention, but later without. To put it simply, there is a dynamic between body, posture, and mind. We keep our body posture and our mind fixed. This does not require intention, so an update of the original mind can occur (ibidem)."

According to Lluís, zazen is a method that allows us to escape from intention, rationality, and the general ordinary functioning of the mind. Through zazen, we accept sensations, emotions, and thoughts, without judging or identifying with them. We let ourselves go, by bypassing intention through concentrating on our body gestures.

In the practice of zazen, we learn how to drive our mind using the body, and especially our breath. The practice of the ritual has a subconscious effect on the mind from the gesture. The ritual is not a dispensable envelope, it nourishes the practice (Salas, 2017: 175, translation from Catalan by me). 
Meditation enables us to let go of our thoughts using the body at a 'subconscious' level. Lluís describes it as the encounter with the 'original mind,' a state of no-intention where we can update our ordinary mind and be fully aware of our enlightened nature. We cannot behold this state permanently, but it is useful for our ordinary mind to work wisely in daily life.

We can't stay there forever, because we need to come back to our daily life, and we need to choose and discriminate thoughts. But after this update occurs, when we return to the dualistic world we see things in a different way [...] We recognize its vacuity, we return with the revelation that everything is empty. This can only be learned from practice itself. We also work with the teachings, and I like to study and transmit them. But they are useful for perfecting the practice, and for making no mistakes, because it is easy to deviate from the true practice [...] The teachings are only there to keep us on the track, but by themselves they cannot reveal what practice shows us (personal interview with Lluís Nansen Salas, April 9, 2017).

\section{Muhō Nölke: A German Abbot in Japan}

Jens Olaf Christian Muhō Nölke ネルケ無方 was born in Berlin in 1968. At the time of the interview, he was the abbot (dōchō 堂頭) of Antaiji, a Sōtō Zen monastery in Japan. During his childhood he lived in Germany, in an old church where his grandfather worked as a minister.

When I was six years old we discovered that my mother had cancer. Until then, she had been working as a doctor [...] She died one year later when she was 37. We had to move from the church because my grandfather was retiring, and my father also had to find a new job. So, we moved to the south of Germany. From the age of 6 to 16, I went to school in the south of Germany [...] And pretty soon I asked myself... [...] if we have to die anyway... why do we live? What's the meaning of life? What's the meaning of going to school every day? [...] why do you have to get a good job to earn money? Why do you need money? [...] what's the meaning of all of that? What's the meaning of playing the game? 
And, in short you would hear that life is a gift from God, and you have to cherish it... [...] I found it hard to believe in this God who is sitting somewhere in the clouds. You can't see him, but he is watching you [laughs], and you should be thankful for the life you have..." (interview with Jens Olaf Christian Muhō Nölke, June 23, 2019).

Muhō's biography has a post-modern background of disenchantment with both Christianity and the Western lifestyle, similar to what we saw in the case of Lluís. When he was 16, he started to study in a Christian school, where he met a teacher who conducted a Zen meditation group for the kids (in Germany there is a Christian Zen tradition where meditation is redirected to connect with God). Initially, Muhō was not convinced he should participate, thinking it could be a kind of cult. But, after talking with the teacher, he decided to give it a go.

So, I tried once, with the intention of telling him it was not for me. But then I went for a second and third time, and today I'm sitting here, so... something worked there. Something clicked. And if I have to tell you what clicked, for me it was the realization, actually... I do not exist only here [Muhō points to his head with his finger] And... there was the breath, there were more sounds outside the window, some birds, the wind is blowing, all stuff that I had completely forgotten about until then. So, what surprised me was that the world was much bigger than I thought (ibidem).

Like Lluís, Muhō initially felt attracted to the practice of Zen without fully knowing the doctrine and history behind it. He was interested in zazen as a way of getting rid of rationality, and discovering a wider world of experience coming from the inner and outer world.

After one year of practicing, the teacher who initially instructed him left the school, so Muho decided to assume the leadership of the meditation group. This new position motivated him to read Buddhist literature such as the Pali sutras and many books written by D. T. Suzuki. That is when he read about the story of Buddha.

There, for the first time, I learned the story of this young prince, Siddhartha, or Shakyamuni, who was born a prince, with a good life, and a wife and children. But he was teaching that life is suffering [...] 
When I heard the story of this prince, it was almost like looking in the mirror. I finally found somebody who was expressing exactly what I always thought! Except for losing my mother when I was 7, I was never short of anything. I always had enough to eat, I always had enough money, I went to school, I had friends. I wasn't missing anything, but I felt... well... at the core there is always something missing.

I think basically the situations today and in Buddha's time are not so different. People realize the game that they are expected to play, it doesn't really have a meaning. It doesn't really have a meaning if you become a prince, and then the king of the kingdom, and you start a war and you win the war, and the kingdom gets bigger and bigger and bigger. And you conquer the whole of India, and you have thousands of kids, and you wear beautiful clothes. It's a meaningless game. But everybody expects to play the game. In every time, at every age, some people wake up to the fact that it is a useless game. So, they look for a place where they can explore different ways of life, or where they can live without taking part (ibidem)."

Muhō decided to go to Japan to continue his training. To be able to do this, he registered on a degree course in Japanese Studies at the University of Berlin. In his Master's degree dissertation, he compared the writings of Eihei Dōgen 永平道元 with German philosophers such as Wittgenstein and Heidegger (Nölke, 1992).

I doubt that Heidegger did any serious research into Zen Buddhism. I mean, he had lots of Japanese students, and he knew about them, but I doubt there was a direct influence... Wittgenstein less so. But at the core, they all ask themselves the same questions, which are basically, why am I here? What is this? What is here? What is the world? [...] What's gonna happen when I die? And how do I live today? [...] But philosophy only thinks about this question, while in Buddhism you've got these people who say, 'let's sit together, let's sit with this question.' [...]

For me the connection with Wittgenstein at the time was the most interesting one. [...] He is a kind of philosopher who changed a lot between youth and old age but... During his older years he said that philosophy is sickness. And the aim of philosophy is to cure that sickness. And this approach is close to what Buddha says so... Buddhism 
is basically to cure the sickness of the feeling that it is not enough [...] For me, Wittgenstein as a philosopher was exciting because he said, the actual goal of philosophy is to quit philosophy. The aim of philosophy is to grow out of it, to cure this disease of philosophy and start to live. So, the connection to Zen is that it says, let's start right now (ibidem).

At the age of 22, Muhō decided to study at Kyōto University for a year. There, he heard stories about Antaiji, a monastery located in the mountains, where monks practice 'true Zen.' Antaiji was founded by Oka Sōtan 大潤宗潭 in 1921 in Gentaku (northern Kyōto), for the practice of zazen and the study of Dōgen's Shōbōgenzō 正法眼蔵. The temple was abandoned during World War II but resumed activity in 1949, when Sawaki Kōdō 祖門興道 took on the role of abbot. Sawaki was an important figure for the transmission of Zen to laypeople, both in Japan and internationally. His teachings had an influence on Zen masters such as Deshimaru. During the 1960s, Antaiji caught the attention of Westerners, some of them hippies, who were welcomed by Uchiyama Kōshō 道融興正, a kind, open-minded abbot. In 1975, Watanabe Kōhō 盡心耕法 succeeded Uchiyama as abbot and turned the temple into a disciplined and harsh environment, so most of the foreigners left. The increase in activity and noise in the surrounding areas made Watanabe Kōhō move Antaiji to the mountains in northern Hyōgo, where the monastery is still currently located. In the mid-1980s, Watanabe decided to travel to Europe to propagate Zen practice, leaving Miyaura Shiny $\bar{u}$ 無 外信雄 in charge of the temple. It was under the guidance of Miyaura that Muhō started his practice at Antaiji.

Initially, Muhō stayed at Antaiji for only six months, practicing zazen, and using Antaiji's library to collect material for his master's dissertation. In 1991, he returned to Berlin and in 1992 he obtained his master's degree. Afterwards, he decided to return to Kyōto, and continue with his $\mathrm{PhD}$, which he never finished. Instead, Muhō returned to Antaiji, and ordained as a monk under the guidance of the abbot Miyaura Shiny $\bar{u}$. He received the name Muhō, which means 'no direction.' It was the year 1993, and Muhō was 25 years old. He stayed in Antaiji for several years. In 1999, he obtained the shihō from Miyaura Rōshi. 
In 1994, Watanabe Kōhō returned to Japan. He was critical of Miyaura Roshi, saying that he should retire and let Muhō be the abbot of Antaiji. The dispute between them put Muhō in an uncomfortable situation. As a consequence, in 2001, Muhō decided to leave the monastery and live as a homeless monk in a park in central Ōsaka, where he met his wife. In February 2002, Miyaura Shinyū was found dead in the mountains. Muhō received a phone call to inform him about the death of his teacher, and to ask him to become the new abbot. Muho became the ninth abbot of Antaiji in 2002. It is now almost 18 years since he became the dōchō of the monastery. He is planning to leave the position, naming as his successor Nakamura Eko 中村恵光, a Japanese woman who has been living in Antaiji for almost 8 years.

In Antaiji, Muhō has been teaching Buddhist philosophy and practice. In his writings on the monastery's website, he encapsulates the main teachings of his master Miyaura, in the sentences: 'You create Antaiji!' 'You don't count at all!' and 'Antaiji is no school. It is an adult sangha!' The sentences are related to what Muhō calls 'Adult Practice.' 'Practice' refers not just to training, but to practicing Buddha's way, which means manifesting something by actually doing it. 'Adult' refers to practice as a great person, in the way of the Buddha and the bodhisattvas. In terms of daily life, it involves stopping the search for a mentor in the abbot, or a haven in Antaiji, and starting to be an adult who creates Antaiji together with the community. It involves giving yourself up to the practice and to Antaiji, going beyond selfish and ego-centered ideas, and abandoning the everlasting quest for something that is missing in your life. During the practice of zazen, one must realize that all these things are part of the 'deluded mind.' For the Enlightened mind, nothing is missing, so there is nothing to seek. According to Muhō, a true adult is capable of embracing both the deluded mind and Buddha's mind. For this to happen, one has to live the karmic human existence under the vows of Buddha's way, and the practice of zazen.

Karma and reincarnation are interpreted by Muhō in a modern and secularized style, similar to Lluís's interpretation, using the idea of 
psychological conditioning, and bypassing the traditional old fashion cosmology.

For me there were only fairy tales. So... I mean different from the Christian's fairy tales of Heaven and Hell, but basically, for me, it was more or less the same thing. If you do something bad now, something bad will happen to you in the future. If you do something good now, something good will happen to you in the future. So, that was a helpful teaching to keep society stable to... how do you say? Motivate people to behave like decent human beings, and not commit crimes, even when they can be sure that nobody will get caught. But I never thought this to be literally the truth. For me, these aspects of Buddhism - karma, reincarnation - were never central to it, I thought, it is kind of a fairy tale. [...] Now I'm open, I'm open to the idea that when this person dies, when Muhō dies, there's still... there is something that is Muhō. [...] I'm open to the idea that when Muhō dies, this consciousness will not die. But I'm not sure about it [...] I don't know. For me it is not the most important thing but I have no scientific evidence to say, 'it's impossible.' Maybe it's possible, I don't know.

I think karma is basically a word for conditioning. What I do now of course changes the future, because it changes what I am, and it is probably going to show in my face, in my speech, so people, when they look at me, to some extent, they look at my karma, they look at Muhō and my past actually changes me. But I do not believe in karma in this way, that if I steal 100 dollars in this life, and I am reborn in the next life, and then, because of that somebody steals 100 dollars from me in the next life or whatever. For me that's a fairy tale but... of course, your actions right now determine who you are. I think that's what karma means (ibidem).

\section{C5. omparative analysis of the two cases}

The qualitative case study presented in this article reveals how cultural translation works in the biographies of two individual cases. Many elements can be explained as part of the sociological and cultural context of Modern Buddhism: the post-modern disenchantment with Western 
emancipatory models and the search for an alternative spiritual path; the scientification and psychologization of Buddhism; the centrality of meditation as a way to escape from a Western style of rational thinking, among others. But the cases also have certain singularities, which involve personal interpretation: for example, how birth and/or death had different emotional impacts, triggering a curiosity for practicing zazen, or how their personal academic interests interacted with their interpretation of both Buddhist practice and doctrine.

Both Lluís and Muhō express the general post-modern disenchantment with Western emancipatory projects, but they each have their own personal style of dealing with the problem. Lluís was left in a void by Catholic institutions and the Western materialistic way of life. He is a physicist and does not reject scientific explanations, but he also appraises the importance of a spiritual perspective to fill the gap between science and his existential inquiries. And Muhō, despite being raised in a German church, describes how he could not believe in God, and how meaningless the Western way of life was for him. He stresses the critical aspects of 'playing the game' of Western life, something that is reflected in how he connects the more defiant aspects of Buddha - such as the prince who abandons his privileges - with the Western critical philosophy of Heidegger and Wittgenstein.

At a biographical level, they both mention the relevance of different turning points for their later encounter with Buddhism. For Lluís, it was the birth of his two sons that connected him with the idea of death, and the need for a spiritual path. For Muhō, it was the early death of his mother that connected him to death, and subsequently mad him aware of the lack of meaning in 'playing the game' in the Western lifestyle. Buddhism offered them both a spiritual path to cope with the idea of death and impermanence, by giving them not only a new understanding of life through the Buddhist's lens, but also an awareness of life as an embodied experience beyond rational understanding, through the practice of zazen. In both cases, the most important factor was meditation as a way to escape from the trap of rational thinking, using the 'body' instead of the 'head.' It was only later that they learned about the doctrine, a path 
that is coherent with Dōgen's view of language, rationality, and practice (Heine, 2021).

The value of meditation as an embodied experience that surpasses rationality is commonly mentioned not only by Zen but by other Buddhist practitioners and other spiritual seekers. Western religious, psychotherapeutic, and philosophical traditions usually offer rational strategies for coping with psychological and existential problems. Spiritual seekers are often disappointed with these perspectives, considering them too 'intellectual.' This is one reason why they become interested in alternative spiritual practices, where embodied experiences, multimodal sensations, dream-like states, and different altered states of consciousness are considered as useful paths to self-knowledge. The post-modern popularization of yoga, Buddhism, martial arts, neoshamanism, New Age, holistic therapies, transpersonal psychology, esoterism, and other spiritual paths, may be related to this shift from rationality to experience (Apud, 2020).

But rationalization also has its place in the spiritual path of spiritual seekers. As we have seen for both Lluís and Muhō, they are also interested in the doctrine, which connects Buddhism to Western ideas in a process of cultural translation. In the case of Lluís, Buddhism can explained in terms of natural sciences, with examples from physics and neuroscience. In the case of Muhō, the connection is more related to humanistic sciences and philosophy. The translation of traditional Buddhist ideas in terms of modern culture is a process in which psychological and historical traits play their part. An example of this are the interpretations of classic koans by female zen practitioners, where gender and cultural biases can be observed (Van Overmeire, 2018).

\section{Conclusion}

In the current article I have focused on two concepts: karma and reincarnation. In the case of karma, it is particularly interesting how both Lluís and Muhō translate concepts in terms of psychological conditioning, understanding the traditional worldview as a metaphor that reflects the idea of how we are conditioned by our own actions and 
thoughts. Similarly, the idea of enlightenment is psychologized in dyadic concepts such as original-ordinary mind, and deluded-adult mind. The question here is, how distant are these cultural translations from traditional Buddhism? Can Buddhism be conceived of without karma and reincarnation in the traditional sense?

For Daniel López Jr. the answer is no (López Jr. ,2008). As he sees it, under a Karmic perspective, consciousness is the product of consciousness. Our past conscious actions are the ones that truly influence our suffering and desires today, so any present moment of consciousness is the result of a previous moment of consciousness. On the contrary, science's idea of causality could be partially related to psychological dispositions, but, at a biological level, life is explained as random mutations and natural selection, excluding intentionality or consciousness in the process.

...karma, rebirth, and the possibility of full enlightenment are among the most important foundations of Buddhist thought and practice. Physicalism, reductionism, and the causal closure principle also are highly important, especially in neuroscience. These are precisely the topics that must be unbracketed and confronted in any discussion of Buddhism and science. It is also among these topics that the most intractable disagreements likely lie. Buddhism is a dualistic system in which mind and matter are different in essential ways, with moments of mind able to be produced only from previous moments of mind; the Buddhist claim that a moment of consciousness can be produced only by a prior moment of consciousness is central to the Buddhist argument in support of rebirth (López Jr., 2010: 893).

Other authors criticize the scope of this argument. For example, Thupten Jinpa (2010) agrees with López Jr. that these epistemic and ontological principles are difficult to conceal. But he also underlines the open dialogue between Buddhism and science that has been ongoing since the end of the 19th century. Throughout this dialogic exchange, both sides have been transformed, and modern forms of Buddhism appeared, as valid as traditional ones. Peter Harrison (2010) criticizes López Jr.'s normative perspective of what counts as genuine Buddhism and what does not. For the author, Buddhism has constantly undergone 
major changes over the centuries, in the same way as science has. From the perspective of the current study, it can be observed how this open dialogue between science and Buddhism works in the biography and ideas of two Western monks. In the case of both Lluís and Muhō, it seems that scientific translations of karma and reincarnation are no obstacle for their being the director of a center (Lluís), or the abbot of a Japanese monastery (Muhō).

In the current article, I used a qualitative biographical approach to understand how these reformulations occur at a psychological level, and in terms of cultural translation. In the two cases presented here, it can be observed how different cultural trajectories intersect within the biography of each case: the religious and cultural background of their childhood, family history, their education, and their spiritual trajectory. Life events, beliefs, practices, and social interactions determine the biographical construction of each individual. Besides, each person imprints a personal style, according to how she/he reacts and reflects on life events. Each individual, as a cognitive, subjective, and psychological unit, acts as a node, where different cultural trajectories intersect. The practitioner's mind is not a tabula rasa, receiving cultural information and reproducing it passively. On the contrary, she/he is a reflexive subject, who is able to rearrange cultural information in accordance to her/his needs and sense of self. Therefore, cultural translations cannot be explained without considering the psychological individual, with her/his personal predispositions and biographical trajectory. 


\section{References}

Almond, P. C. (1988) The British Discovery of Buddhism. New York: Cambridge University Press.

Apud, I. (2015) "Ayahuasca from Peru to Uruguay: Ritual Design and Redesign through a Distributed Cognition Approach" Anthropology of Consciousness, 26 (1): 1-27.

- (2017) "Science, Spirituality, and Ayahuasca. The Problem of Consciousness and Spiritual Ontologies in the Academy" Zygon. Journal of Religion and Science, 52 (1): 100-123.

- (2020) Ayahuasca: Between Cognition and Culture. Perspectives from an Interdisciplinary and Reflexive Ethnography. Tarragona: Publicacions URV.

Apud, I., Clara, M. and Ruiz, P. (2013) "Linajes Budistas En Uruguay" Ilu, 18:9-25.

Apud, I., Clara, M., Ruiz, P., and Valdenegro, A. (2015a) "Buddhism in Uruguay" In Gooren, H. P. (ed.) Encyclopedia of Latin American Religions, Vienna: Springer International Publishing. 131-134.

- (2015b) "Seis Grupos Budistas En El Uruguay de Siglo xxi" Anuario de Antropología Social y Cultural En Uruguay, 13: 135-44.

Asad, T. (1975) Anthropology and the Colonial Encounter. London: Ithaca Press.

Baumann, M. (2001) "Global Buddhism: Developmental Periods, Regional Histories, and a New Analytic Perspective" Journal of Global Buddhism, 2: 1-43.

Berkwitz, S. C. (2006) Buddhism in World Cultures. Comparative Perspectives. Santa Barbara: ABC Clio.

BLoch, M. (2012) Anthropology and the Cognitive Challenge. Cambridge: Cambridge University Press.

Boyer, P. (1994) The Naturalness of Religious Ideas. Los Angeles: University of California Press.

Bretfeld, S. (2012) "Resonant Paradigms in the Study of Religions and the Emergence of Theravāda Buddhism" Religion, 42 (2): 273-97. 
Cabezón, J. I. (2003) "Buddhism and Science: On the Nature of the Dialogue." In Wallace, B. A. (ed.) Buddhism \& Science. Breaking New Ground. New york: Columbia University Press. 35-68.

Coleman, J. W. (2001) The New Buddhism: The Western Transformation of an Ancient Tradition. New York: Oxford University Press.

Díez de Velasco, F. (2013) El Budismo En España. Historia, Visibilización e Implantación. Madrid: Akal Universitaria.

Harrison, P. (2010) "A Scientific Buddhism?" Zygon. Journal of Religion and Science, 45 (4): 861-69.

Heine, S. (2021) “Just Sitting and Just Saying: The Hermeneutics of Dogen's Realization-Based View of Language" Religions, 12 (81): 1-16.

Heine, S., Prebish, C. (2003) Buddhism in the Modern World: Adaptations of an Ancient Tradition. New York: Oxford University Press.

James, W. (1902) The Varieties of Religious Experience: A Study in Human Nature. Being the Gifford Lectures on Natural Religion Delivered at Edinburgh in 1901-1902. London: Longman, Green \& Co.

JinPA, T. (2010) "Buddhism and Science: How Far Can the Dialogue Proceed?" Zygon. Journal of Religion and Science, 45 (4): 871-82.

López JR., D. S. (1995) Curators of the Buddha. The Study of Buddhism under Colonialism. London: University of Chicago Press.

- (2008) Buddhism \& Science. A Guide for the Perplexed. Chicago \& London: University of Chicago Press.

- (2010) "The Future of the Buddhist Past: A Response to the Readers" Zygon. Journal of Religion and Science, 45 (4): 883-96.

Lyotard, J-F. (1993) La Condición Posmoderna. Barcelona: Editorial Planeta. McMahan, D. L. (2004) "Modernity and the Early Discourse of Scientific Buddhism" Journal of the American Academy of Religion, 72 (4): 897-933.

- (2008) The Making of Buddhist Modernism. Oxford \& New York: Oxford University Press.

McNamara, P. (2009) The Neuroscience of Religious Experience. New York: Cambridge University Press.

Nölke, O. (1992) "Das Genjōkōan von Eihei Dōgen (1200-1250) - Eine Gegenüberstellung Und Kritik Der Kommentare Und Philosophischen 
Vergleiche, Sowie Der Übersetzung in Westliche Sprache". Berlin: Freie Universität Berlin.

Prat, J.; Anguera, M.; Caudet, F.; Dittwald, D.; Reche, J.; Tomás, I. and VIVANCos, I. (2012) Els nous imaginaris culturals. Espiritualitats orientals, teràpies naturals i sabers esotèrics. Tarragona: Publicacions URV.

PREBISH, C. S. (1999) Luminous Passage: The Practice and Study of Buddhism in America. Berkeley \& Los Angeles: University of California Press.

SAID, E. (1994) Orientalism. New York: Vintage Books.

SALAS, L. N. (2017) Meditació Zen. L'art de Simplement Ser. Barcelona: Viena Edicions.

- (2018) Mindfulness Zen. La Consciència de l'ara. Barcelona:Viena Edicions.

- (2019) Dharma Zen. L'ull de La Joiosa Revelació. Barcelona: Viena Edicions. Sharf, R. H. (1995) “The Zen of Japanese Nationalism." In Lopez JR., D. S. (ed.) Curators of Buddha. The Study of Buddhism under Colonialism. Chicago: The University of Chicago Press. 107-160.

Sperber, D. (1996) Explaining Culture. A Naturalistic Approach. Oxford \& Cambridge: Blackwell Publishing.

Starbuck, E. D. (1911) The Psychology of Religion. An Empirical Study of the Growth of Religious Consciousness. New York: The Walter Scott Publishing Co.

Stuckrad, K. (2014) The Scientification of Religion: An Historical Study of Discursive Change, 1800-2000. Berlin: De Gruyter.

Taussig, M. (1993) Xamanismo, Colonialismo e o Homem Selvagem. Rio de Janeiro: Paz e Terra.

Tweed, T. A. (2000) The American Encounter with Buddhism, 1844-1912: Victorian Culture and the Limits of Dissent. Chapel Hill: University of North Carolina Press.

Znamenski, A. (2007) The Beauty of the Primitive Shamanism and the Western Imagination. New York: Oxford University Press. 